The second edition has only 476 pages and eleven chapters. In this edition, the authors tried to eliminate errors that appeared in the first edition and omit those methods that were considered impracticable or unnecessary. They also added some new methods, which had proved to be useful for physicians. They improved the text by the inclusion of additional chapters, such as the chemical analysis and hygienic determinations of milk. The iconography was improved by adding a further 35 figures and the bibliography was extended by 9 additional titles.

Although for a quarter of century this book was very useful in almost all clinical laboratories in Romania and in many departments of biochemistry of different faculties from our country, it was considered a basic book, but, paradoxically, very little has been written since 1948 . The reason lies in the fact that both authors became political undesirables at the beginning of the communist period. Ioan Manta was thrown out of the educational system in 1949 and imprisoned between 1949 and 1951 (6). In 1952, he was allowed to continue his academic career in Cluj, starting in the Faculty of Pharmacy. In 1953, he came back as the Chair of Biological Chemistry from the Faculty of Medicine (7). Alexandru Ciplea was also eliminated from the academic educational system in 1952. In 1960, he became a researcher at the Physiology Department led by Prof. Grigore Benetato (1905-1972) at the Bucharest Institute of Medicine and Pharmacy.

In conclusion, there are sufficient arguments to consider this book as having a very important place in the Romanian history of laboratory medicine, because it marked a step in its evolution.

\section{Cristian Barsu}

Department of History of Medicine, Social Sciences and Humanism, "Iuliu Hatieganu" University of Medicine and Pharmacy, Cluj-Napoca, Romania

\section{REFERENCES}

1. Manta I. Introducere (Introduction). In: Manta I, Ciplea Al, editors. Metodele Laboratorului Clinic (The Methods of the Clinical Laboratory). Sibiu: Cartea Romaneasca din Cluj (Romanian Book from Cluj) Publ. House; 1944:V.

2. Hatieganu I. Prefata (Preface). In: Manta I, Ciplea Al, editors. Metodele Laboratorului Clinic (The Methods of the Clinical Laboratory). Sibiu: Cartea Romaneasca din Cluj (Romanian Book from Cluj) Publ. House; 1944:VI.

3. Thomas P. Manuel de Bichimie (Biochemistry Textbook). Paris: Masson et Cie Éditeurs; 1936:866.

4. Desgrez A. Précis de Chimie Médicale (Textbook of Medical Chemistry). Paris: Librairie J.-B. Baillière et fils; 1921:442-5.

5. Goia I. Ficatul. Notiuni anatomo-morfo-clinice The Liver. Anatomo-morpho-physiological notions. In: Hatieganu I, Goia I, Hanganut M, Sparchez T, editors. Tratat Elementar de Semiologie si Patologie Medicala (The Medical Semiology and Pathology Elementary Treatise), vol. III. Cluj: Cartea Romaneasca (Romanian Book) Publ. House; 1938.

6. Barsu C. Testimonials about the life of Prof. Ion Manta (19001979), a victim of communist regime. Cj Med 2013;86:388-9.

7. Mircioiu C. Alexandru Ciplea. In: Simiti I, editor. Figuri Reprezentative ale Medicinii si Farmaciei Clujene (Representative Figures of Cluj Medicine and Pharmacy), vol. IV. Cluj-Napoca: IMF Printing House 1988:17-24.

\title{
Comment on The Significance of a Neglected Romanian Book - "The Methods of the Clinical Laboratory", by Ioan Manta and Alexandru Ciplea
}

I am very pleased to comment such an article reviewing the book "Metodele laboratorului clinic" (title in English: "The Methods of the Clinical Laboratory") (1) since I know one of the authors very well, as well as the importance of the book.

Professor Ioan Manta was the Founder and for several decades the Chairman of the Department of Medical Biochemistry of the University of Medicine and Pharmacy in Cluj-Na- poca, Romania. As other students in medicine, I was greatly impressed by Professor Manta's outstanding lectures, in which the great importance of biochemistry and molecular biology for medicine (and for the clinical laboratory in particular) was emphasized. Some of his students decided to engage in research in his department during their medical studies. Professor Manta ensured an excellent environment for both teach- 
ing and research, was an excellent mentor, asking other staff members to introduce students to research programs within the department. Under the supervision of a very dedicated Lecturer, Dr. Adriana (Popesco) Hodârnău, and together with two colleagues, we pursued a project of research involving chromatography of amino acids that resulted in the publication of a paper in an international journal, which was well known at the time (2). Afterwards, Professor Manta made great efforts to help me to obtain several positions in his department $(\mathrm{Ph}$ D student, Lecturer, Senior Lecturer), and to obtain the approval to work as a Postdoc in England (I was later appointed to Chair of the new Department of Cell Biology). All of these steps were very difficult to pursue during the "Communist Regime", which led to Professor Manta suffering a lot (he was even imprisoned for several years, during the Second World War after he undertook several visits to Germany, even though he was sent by the University to buy equipment and consumables for all laboratory departments).

Professor Ioan Manta was the founder of Medical Biochemistry in Romania, devoting a lot of his time to practical problems of the clinical laboratory. This was all in a time when links with other countries were cut (first because of the War, then due to the "Communist Regime"). Consequently, it was extremely important for specialists working in medical laboratories (hematologists, chemists, biologists, and pharmacists) to have methods to use in their analyses upon which clinicians could base the diagnosis and treatment of patients.

Professor Manta, along with another clinician, Alexandru Ciplea, took on the difficult task of writing a book on such methods. They successfully wrote an excellent book, which was on the benches of every for decades medical laboratory in Romania for decades; the users called it the "Manta-Ciplea book". At some point, Professor Manta told us of a visit to a Romanian laboratory where he was introduced by the Head of a Clinic and one of the people in the lab said: "Ah, you are Mr. Manta-Ciplea!".

In 1974, while I was a Lecturer in his Department, Prof. Manta called me one morning and expressed his wish to produce another practical book for clinical laboratories, containing just biochemical methods, as in the meantime the medical (clinical) laboratory had been divided into several sub-specialties (hematology, biochemistry, microbiology, parasitol- ogy, immunology, etc.). He asked me to be a co-author of a new "methods" book and even gave me the task of identifying other coauthors.

I felt honored and also very enthusiastic, and managed to find two other authors: Mircea Cucuianu (the Director of the best clinical laboratory in Cluj-Napoca, the First Medical Clinic; he later became the first Professor of Clinical Biochemistry and the founder of this discipline in Romania) and Adriana Hodârnău. Together, we produced a highly successful book: ("Metode biochimice în laboratorului clinic", in English: "Biochemical Methods in the Clinical Laboratory" (3)), which was published in 1976. The book was used for many years in all clinical laboratories in Romania, before new analyzers were introduced (after 1990).

To conclude, I agree that the book by Prof. Ioan Manta-Alexandru Ciplea was for decades a reference book and believe that it is important to pay tribute to such books and their authors.

\section{Gheorghe Benga ${ }^{1,2,3,4,5,6}$}

${ }^{1}$ Cluj County Emergency Hospital - First Laboratory for Genetic Explorations, Cluj-Napoca, Romania

2"Vasile Goldis" Western University of Arad, Discipline of Cell and Molecular Biology, Arad, Romania

${ }^{3}$ Romanian Academy, Cluj-Napoca Branch, Cluj-Napoca, Romania

${ }^{4}$ Academy of Medical Sciences, Cluj-Napoca Branch, Cluj-Napoca, Romania

${ }^{5}$ The Gheorghe Benga Foundation, Cluj-Napoca, Romania

${ }^{6}$ The OUTNOBEL Foundation, Cluj-Napoca, Romania

\section{REFERENCES}

1. Manta I, Ciplea A, editors. Metodele laboratorului clinic (in English: The Methods of the Clinical Laboratory), Editura Cartea Românească, Cluj, 1944.

2. Popesco A, Benga Gh, Coman D, Pop V. L'etude comparative des acides amines libres, seriques et biliaires, dans les maladies du foie. Rev Int d'Hepatol 1966;16:1419-28.

3. Manta I, Cucuianu M, Benga Gh, Hodârnău A, editors. Metode biochimice în laboratorul clinic (in English: Biochemical Methods in the Clinical Laboratory), Editura Dacia, Cluj-Napoca, 1975. 